\title{
A követendő példa, avagy milyen a jó cyberbullying kézikönyv
}

Az internet robbanásszerű elterjedésével és térhódításával nemcsak annak pozitívumai, hanem számos veszélyt magában rejtő negatívumai is napjaink részévé váltak. Az ártatlanabbnak tűnő profilfeltörésektől a személyiséglopáson át az országokat megbénítani képes hackerkedésig számtalan potenciális veszélyforrás jelentkezik a lakosságra nézve. Ilyen veszélyforrás az iskoláskorú fiataloknál felmerülő, hazánkban szinte alig kutatott jelenség, az ún. cyberbullying. Az itt recenzált kézikönyv ${ }^{1}$ ezt a témakört járja körül.

\section{A cyberbullying fogalma}

A cyberbullying vagy magyar terminológiával cybermegfélemlítés keretébe tartozik minden olyan magatartási forma, amely során iskoláskorú fiatalok kortársaikat vagy az iskolai alkalmazottakat a virtuális térben elektronikus eszközökkel megfélemlíteni, megalázni, zaklatni, nevetségessé tenni szándékoznak. Jelenleg sem külföldön, sem hazánkban nincs olyan egységes, elfogadott fogalom, amely pontosan leírná e magatartást. Mindez a jelenség komplexitásából és rendkívül változatos elkövetési módjaiból adódik, hiszen amint az egyik elkövetési módot szabályozzák, azonnal fellép egy újabb. Ebből kifolyólag a szakirodalom fogalmi elemeket állapít meg, amelyeknek szükségképpeni elemként kell megjelenniük bármely cybermegfélemlítés fogalomban. A hazánkban uralkodó, külföldi szakirodalomra támaszkodó tudományos álláspont szerint az alábbi elemek megvalósulása szükséges a cybermegfélemlítés megvalósulásához: (i) virtuális térben; (ii) elektronikus eszközzel történő elkövetés; (iii) ismétlődő jelleg; (iv) támadó jellegü, offenzív magatartás; és (v) az erőegyensúly felborulása.

Ezen elemek tartalmáról, illetve szükségességéről természetesen lehet, sőt indokolt tudományos vitát indítani. Amennyiben ugyanis komoly tudományos vita nélkül próbáljuk meg felhívni a figyelmet a problémára, abba a hibába esünk, amelybe a Médiaunió kampánya, mégpedig, hogy rossz fogalmat közvetítünk a társadalom felé, amely így félreinformálttá válik a jelenséget illetően. Hazánkban az utóbbi években több publicisztika is megjelent, amely elektronikus zaklatásként - vagy még

* Dr. Pongó Tamás PhD-hallgató, Szegedi Tudományegyetem Állam- és Jogtudományi Kar Alkotmányjogi Tanszék, pongo.tamas@juris.u-szeged.hu.

1 Hinduja, Sameer-PATCHIN, Justin W.: Bullying Beyond Schoolyard-Preventing and Responding to Cyberbullying. Corwin, California, 2015. 
pontatlanabbul, internetes zaklatásként - jelölte a cybermegfélemlítést. ${ }^{2}$ Habár vitathatatlan, hogy ezen elkövetési módok is cybermegfélemlítési formák, azonban nem írák le a jelenség minden aspektusát.

Egy rövid példával érzékeltetve: Egy tinédzser pár ifjonti hévtől vezérelve egymásról meztelen képeket készít, amelyeket kizárólag az egyikőjük számítógépén tárolnak, $s$ a szakítást követően a képek birtokában lévő fél további képeket követel a másiktól, kilátásba helyezve a korábbi képek Facebookon való megosztását, ha nem kap újabbakat. Mindez önmagában nem zaklatás (bár természetesen azzá válhat), viszont cybermegfélemlítés. Ha a fenti példában a képek birtokában lévő fél kérdés nélkül megosztja egy középiskolai osztály zárt Facebook-csoportjában a képet, zaklató elem akkor sem jelenik meg, ugyanakkor szintén cybermegfélemlítésként definiálható a magatartás. Jogos kérdésként merül fel e második példa kapcsán, hogy az ismétlődő elem itt miként jelenik meg. Erre a recenzált mű akként adja meg a választ, hogy az ismétlődés valós lehetősége már kimeríti ennek az elemnek a megvalósulását. ${ }^{3}$

\section{A kötet módszertana}

A kötet a 18 év alatti, iskoláskorú fiatalok körét vizsgálja, és célja többek között a cyberbullying jelenségével kapcsolatban használt terminológia meghatározása, pontosítása is. A könyvet a szerzők kézikönyvnek nevezik, amely nem csak jogászok számára lehet hasznos. Mindkét szerző PhD-fokozattal rendelkező, büntető igazságszolgáltatással foglalkozó szakember ugyan, ám a mü nem „erölteti rá” az olvasóra a büntetőjog szigorú és zárt definíciókban való gondolkodásmódját, sőt büntetőjogi eszközökröl alig tesz említést. Mindez nagy érdem és előny, hiszen a büntetőjogi dogmatikában való elmélyülés még a jogász végzettséggel rendelkezőktől is komoly tudást igényel, ennek elhagyásával azonban a nem jogász olvasók számára is élvezetes a kötet. A szerzők a tudományos megállapítások mellett igyekeznek általános ismeretterjesztő nyelvezettel is bemutatni a vizsgált problémákat.

A kézikönyvjellegből adódóan a mű jól felépített, átlátható rendszerben kíséri végig az olvasót a témán. Az egyes fejezetekben tipográfiailag jól elkülönítve valós történetek, idézetek jelennek meg, a fejezetek végén pedig összegzés és vitaindító kérdések is helyet kapnak. Tekintettel arra, hogy a prevenció, a tudatosságra nevelés csak párbeszéd útján valósulhat meg, e vitaindító kérdések gyüjteménye különösen nagy segítséget nyújt ezen a területen. Az egyes fejezetek végén a tárgyalt témakörhöz kapcsolódó felhasznált irodalom jegyzéke a további tudományos kutatáshoz nyújt jó kiindulópontot.

2 Zaklatnak az interneten - mit tegyek?, hvg.hu, 2011. augusztus 9., http://hvg.hu/tudomany/20110809_internet_zaklatas_tippek (2016. 09. 01.); Zalavári Noémi: Miért írják a lányomnak, hogy kösd fel magad?, hvg.hu, 2015. október 28., http://hvg.hu/itthon/20151027_mert_irjak_webes_zaklatas_cyberbullying (2016. 09. 01.); Kovács Andrea: Online zaklatás: kinek fáj, hogy fáj?, hvg.hu, 2016. március 28., http://hvg.hu/ tudomany/20160328_online_zaklatas_kinek_faj_hogy_faj (2016. 09. 01.).

3 Hinduja-Patchin: i. m., 12. 
Az előszóban a szerzők részletesen ismertetik a könyv szerkezeti felépítését, ami hasznos azon olvasók számára, akik csupán a cybermegfélemlítés egyes részei iránt érdeklődnek, vagy kellő előképzettséggel bírnak, s így számukra az alapvető ismeretek átolvasása nem nyújt új információt. Jogász olvasóként nagyra értékeltem, hogy például a jogi háttér főbb irányvonalait már az előszóban megismerhettem.

\section{Tartalmi áttekintés}

Az előzőekben bemutatott módszernek megfelelöen az első fejezet Amanda Todd cybermegfélemlítés-áldozat rövid történetével indul, amely azonnal szembesíti az olvasót e jelenség extremitásával. Ez az általános áttekintő fejezet tömören felvázolja, hogy mit takar az offline (virtuális világon kívüli, valós életben történö), hagyományos értelemben vett megfélemlítés (bullying), melyek a fogalmi elemei és hogyan kapcsolódik a cybermegfélemlítéshez. Habár az érvelések logikusak és következetesek, némi kritikával illethetők, ugyanis a cybermegfélemlítés szinonimájaként fogadják el az SMS bullying, digital bullying és a cyberzaklatás fogalmakat, ám ezek inkább egyes aspektusai, részelemei a gyüjtöfogalomként müködő cybermegfélemlítésnek. Érdekes, hogy a szerzők az erőegyensúly felborulását nem tartják kifejezett fogalmi elemnek (bár jelzik, hogy általában megjelenő elem), mivel az a virtuális térben gyakran változik és amorf.

Az első fejezet röviden bemutatja a jelenség lényegét, de azt napjaink fiataljaira vonatkozóan a második fejezet pontosítja. Itt megismerhetjük, hogy milyen felületeken élik online életüket a vizsgált fiatalok, s e felületek miként müködnek, mely müködési formájuk miatt vonzzák a fiatalok tömegeit. A Twitter például rövid szöveges üzenetek küldésére alkalmas, ahol a \# (hashtag) jelzéssel bármilyen nagy, világszintủ beszélgetésbe is bekapcsolódhatunk. A leírtakhoz több, fiataloktól származó idézet is társul, így válik igazán érthetővé, életszerűvé, hogy miért bírnak olyan nagy jelentőséggel e platformok a fiatalok életében.

Miután az első két fejezet bemutatta a fiatalok által használt virtuális teret, a harmadik már a cyberbullying jelenségének elemeire és megvalósulási formáira összpontosít. E három fejezet átolvasását követően világossá válik a cybermegfélemlítés dinamikája és technológiai háttere, amely tudás elengedhetetlen a jelenség elleni küzdelemhez.

A szerzők szerint hat kulcselem teszi vonzóvá az elkövetők számára a cybertérben való elkövetést: (i) anonimitás és pszeudonimitás; (ii) akadálytalanság; (iii) deindividualizáció; (iv) felügyelet hiánya; (v) vírusszerü, gyors szétterjedés lehetősége; (vi) az áldozattá válás kockázatának korlátlan lehetősége. Az egyes elemek bemutatása révén tisztább képet kaphatunk arról, hogy miért terjedt el és jelent ekkora veszélyt a cybermegfélemlítés. A fejezet az elkövetési formákat is körvonalazza, jelezve természetesen, hogy ezek mellett számos további magatartás létezhet. A leggyakrabban előfordulók a következők: (i) pletyka terjesztése; (ii) gyalázkodó üzenetek, hozzászólások közzététele (flaming); (iii) képek, videók posztolása; (iv) képaláírás, hozzászólás, üzenetváltás; (v) információterjesztés; (vi) személyiséglopás; (vii) megjelölés („tagelés”); (viii) cyberzaklatás egy erősebb típusa (cyberstalking); (ix) fizikai fenyegetés. 
Az alapvető ismeretek átadása után a könyv bemutatja a szerzők 2007-2014 között végzett empirikus kutatásainak menetét és eredményeit. Itt található az a mondat, amely ezen a területen minden további kutatás mottójaként szolgálhatna: „A cyberbullying áldozataként vagy elkövetöjeként egyetlen gyermek is túl sok." A felmérések számszerúen is bizonyítják, hogy a cybermegfélemlítés valóban erőteljesen jelen van a 18 éves kor alatti diákság körében. A kutatási eredményeket a szerzők különböző szempontok alapján mutatják be, így nem, életkor és etnikai hovatartozás szerint. Láthatóvá válik az is, hogy az áldozatok kikkel osztják meg az őket ért atrocitás élményét, illetve milyen válaszreakciókat adnak a cybermegfélemlítésre. A szerzők röviden kitérnek a jelenség által indukált, esetlegesen bekövetkező érzelmi és viselkedésbeli következményekre is. A fejezet lezárásaként néhány megtörtént eseten keresztül megismerhetjük a „cyberbullicide”, azaz a cyberbullying miatt elkövetett öngyilkosság fogalmát.

A következőkben a szerzők a téma jogi hátterét, illetve a jogi problémákat körvonalazzák. Ennek keretében ismertetik azt a négy alapvető szövetségi legfelsőbb bírósági döntést, amelyek lefektették a diákok campuson történő véleménynyilvánításának alapjait az Egyesült Államokban, és amelyek az offline megfélemlítéshez kapcsolódnak. A jogász végzettségủ vagy jog iránt érdeklődő olvasók számára rendkívül érdekes témakör ez, ám az ítéletekböl kiemelt részek igen kevés jogi érvelést tartalmaznak, így a szerzők által felvillantott rövid esetleírások mellett szükséges az eredeti ítéletek, illetve a vonatkozó szakirodalom feldolgozása is. Annak ellenére, hogy az USA bíróságai az eléjük kerülő cybermegfélemlítési eseteket kivétel nélkül ezen offline ügyekre való hivatkozással döntik el, a szerzők nem szenteltek túl nagy terjedelmet ezek ismertetésére. Álláspontom szerint bővebb elemzés lett volna indokolt ebben a részben, hiszen a teljes USA-beli esetjog alapköveit képezik e döntések.

Az offline esetekhez képest a cybertérben történt ügyek elemzése sokkal részletesebb. A szerzők kellően körbejárják az egyik legfontosabb problémát: azoknak az ún. off-campus eredetü (az iskola területén, iskola által felügyelt helyen, rendezvényen, eseményen kívüli) szólásoknak a megítélését, amelyek a campuson fejtik ki hatásukat. Az esetjogból levont következtetések valóban helytállóak, s a könyv egyik legnagyobb pozitívuma, hogy többek között a floridai és kaliforniai törvények alapján igyekszik iránymutatást adni a probléma jogi megoldásához. Mindez azért bír kiemelt jelentőséggel, mert a törvények felkutatása és tartalmuk megismerése, értelmezése nem várható el egy jogi végzettséggel nem rendelkező tanártól, ugyanakkor, ha egy tanár e könyvet elolvassa, tisztább képet kap arról, hogy milyen határok között mozoghat, illetve hogy miként ismerheti meg a saját államának szabályait. Az esetjog jogalkotással való összekapcsolása jelen könyv egyik legnagyobb érdemeként említhető. A szerzők azonban nem elégedtek meg ennyivel, ugyanis mintákat is készítettek a jelenséggel szembesülők számára: mintafogalmakat alakítottak ki, a cybermegfélemlítés jelentésének és eljárási módjának egyfajta mintáját is felvázolták, és fegyelmezési opciókat is javasolnak az ilyen szituációk kezelésére.

4 Hinduja-Patchin: i. m., 79. 
Jogászként úgy vélem, a könyv egyik legfontosabb része e fejezet, amely a jogász és nem jogász olvasóval egyaránt megismerteti az irányadó offline és online esetjogot, annak hibáival együtt, s mindezt összekapcsolja a hatályos jogalkotással. Továbbá a tényszerü megállapításokon túl megoldási javaslatokat is nyújt, ami a legtöbb hasonló munkából hiányzik vagy csak érintőlegesen, általánosságban jelenik meg.

A jogi háttér feltérképezését követően a cybermegfélemlítés elleni küzdelem egyik legfontosabb eszközét, a prevenciót veszik górcső alá a szerzők. Ennek keretében a tanárok szerepének fontosságára hívják fel a figyelmet, és megoldási javaslatokat is nyújtanak. Eszerint elsőként fel kell mérni a jelenség állapotát az iskolában, így a status quo ismeretében fel lehet építeni a megfelelő stratégiát. A felmérés segítése érdekében mintakérdéseket adnak közre, amelyek segítségével a tanárok számára pontosabb helyzetfelmérés elkészítése lehetséges.

A diákok és tanárok oktatása is fontos elemként jelenik meg, a könyv ehhez is számos jó tanáccsal szolgál. Példaként említhető a témához kapcsolódó, médiából ismert esetek megbeszélése a diákokkal, az eset okainak elmagyarázásával, bemutatva, hogy felelősségteljesebb elektronikus eszközhasználattal miként lett volna megelőzhető az esemény. Magától értetődőnek hathat azon fontos tanács, hogy egy pillanatra álljunk meg, mielőtt valamit az interneten megosztunk, hiszen ami most nem bír akkora jelentőséggel, az a későbbiekben pokollá teheti egy tinédzser életét. Mindezek mellett az egyik legfontosabb, tanárok által alkalmazható prevenciós eszköz a követhető, logikus technológiahasználatra vonatkozó szabályzat. Amennyiben az adott oktatási intézményben a technikai eszközök használatának szabályozása terén ellentmondás áll fenn, úgy a diáktól nem várható el, hogy szabálykövető módon cselekedjen. E probléma elkerülése végett a könyv mintaszabályzatot tartalmaz, amely kiindulási alapként szolgálhat bármely oktatási intézmény számára. A szabályzat mellett javasolt internetes szürőprogramok telepítése arra az esetre, ha a nyilvánvaló és minden diák által megismerhető szabályzat ellenére mégis szabályellenes magatartás valósul meg. A szabályzat megalkotása és a szürőprogramok telepítése mellett indokolt az iskolában megfélemlítés elleni program bevezetése vagy más intézményből való átvétele, hiszen a felmerülö esetek kezelésére szükséges egy szakmailag megalapozott válaszmechanizmus.

Habár az oktatók általi fellépés elengedhetetlen a cybermegfélemlítés kezelése terén, a szülők legalább annyira, ha nem még fontosabb láncszemei ennek a gépezetnek. A szülők oldaláról a kommunikáció kiemelten fontos, hiszen a tinédzser korúak nem szívesen osztják meg gondolataikat a felnőttekkel, szülőkkel. Ugyanakkor szükséges tisztázni velük, hogy hol húzódnak a határok, például mely oldalak látogathatók az interneten, s melyek nem. Indokolt lehet felhívni a gyermek figyelmét arra, hogy a mobiltelefon és az internethasználat kiváltság, nem pedig jog, ami mindenkor jár számára. Természetesen ebbe beletartozik, hogy a szülő is tiszteletben tartja a gyermeke magánéletét, és teret hagy számára a kortársaival való érintkezésben. A gyermek viselkedését mindig figyelemmel kell kísérni, így ha abban változás áll be, óvatosan fényt kell deríteni a problémára, amilyen hamar csak lehetséges. Kérdésként merülhet fel, hogy mikortól legyen Facebook-profilja a gyermeknek. A szerzők szerint erre nincs egzakt életkori válasz, de előnyösebb, ha a szülő vezeti be gyermekét az internet világába, mintha barátok teszik meg azt. 
A tanárok és a szülök prevencióban játszott szerepe mellett kérdés, hogy mit tehetnek maguk a diákok az áldozattá válás elkerülése és a biztonságos internethasználat érdekében. Elsőként említendő a személyes adataikra való odafigyelés tudatosítása a szülök, de akár barátok révén. Napjainkra elterjedtté vált, hogy a fiatalok fényképet készítenek arról, hol járnak, és megosztják azt a különböző közösségi oldalakon, ugyanakkor kevés figyelmet fordítanak arra, hogy ki láthatja az adott bejegyzést. Tudatosítani kell minden gyermekben, hogy az interneten olyanok is követhetik a mindennapjaikat, akik nem ismerik öket, vagy visszaélhetnek a nyilvánosan hozzáférhető adataikkal. Ilyen személyes adatnak minősülnek a különböző felületeken használt jelszavak is, amelyek megosztásától érdemes tartózkodni.

Kritikaként említhető e ponton, hogy diákoknak szánt prevenciós megoldási javaslatokból csupán kettőt említ a könyv, ami túl kevés. További javaslatként jelenhetett volna meg, hogy ha a szülökkel nem kívánnak ilyen témákról beszélni, akkor keressenek egy megbízható felnőttet, aki segít kezelni a problémát. Emellett érdemes lett volna kiemelni, hogy amennyiben egy fiatal „szemlélöként” (bystander) cybermegfélemlítés cselekményt észlel, azt azonnal jelentse a megfelelő személynek, ezáltal is elítélve a helyzetet és elösegítve annak megoldását. Mindezek ellenére úgy vélem, a prevenciós fejezet kellöen részletes, a minták révén megfelelő iránymutatásul szolgálhat és komoly segítséget jelenthet tanárnak, szülőnek, diáknak egyaránt. A fejezet zárásként olyan magatartási mintákat is felsorol, amelyekböl arra lehet következtetni, hogy cybermegfélemlítést, elkövető egy gyermek.

Sajnos sok esetben a prevenciós módszerek nem vezetnek eredményre, és a cybermegfélemlítés megvalósul. Ezen esetekben határozott válaszreakciók indokoltak. A következő fejezet ezzel a témával foglalkozik. A könyv logikai felépítését dicséri, hogy a prevenció után tárgyalja a válaszreakciókat, nem közvetlenül a jogi fejezet után. Habár mindez csupán szerkesztési elv, e logikai elrendezés azt sugallja az olvasó számára, hogy a jelenség több szempontból (így jogi aspektusból) való megismerése után a prevenció az első fontos lépés. Ezt az üzenetet mindenképpen fontosnak tartom. E fejezet követi az előző szerkezeti felépítését, így elsőként az iskolák lehetőségeit tárja fel, majd a szülőkét, ezt követően a diákokét $s$ végül a jogi opciókat.

Az iskolák számára a szerzők egy jól áttekinthető, összegző táblázatban felsorolják a legfontosabb teendőket, ha cybermegfélemlítés eseményről értesülnek. Szintén táblázatos formában osztályozzák a leggyakoribb elkövetési magatartásokat súlyosságuk szerint, amelyekhez így hozzárendelhető a megfelelő válaszreakció, és elkerülhető, hogy „ágyúval lőjenek verébre” a problémával szembesülő iskolai alkalmazottak. A szerzők arra biztatják az iskolai dolgozókat, hogy legyenek kreatívak a válaszreakciók alkalmazása során, azaz ne egyböl a punitív szankciókat részesítsék elönyben. A szankciókat is az említett táblázat figyelembevételével tanácsos kiszabni, például az elkövető számára kötelezővé tenni egy cybermegfélemlítés elleni plakát elkészítését, amit utána iskolaszerte kiragasztanak. Mindezek mellett fontos, hogy az áldozathoz pozitívan, az érzelmi helyzetét figyelembe véve, kellő érzékenységgel közelítsünk, ugyanis a fiatalok gyakran vágynak a segítségre, azonban attól félnek, hogy a szülöi vagy tanári beavatkozás csak tovább ront a helyzetükön. 
A fent említett válaszreakciók a két érintett félre (az áldozatra és az elkövetöre) fókuszálnak, a szerzők azonban igen hatékonynak tartják a harmadik személyeket bevonó, ún. névtelen jelentési rendszer fenntartását. Az anonimitás, mint már említettem, kulcsfontosságú a cybermegfélemlítés témakörében, hiszen az elkövetök sokszor névtelenek maradnak. Ugyanakkor a megoldáshoz vezető úton is értékes lehet az anonimitás. A diákok ugyanis, ha bystanderként (szemlélöként) szemtanúi a virtuális térben elkövetett cybermegfélemlítésnek, általában nem merik azt a felnőtteknek jelenteni, mert félnek, hogy retorzióként ők kerülnek az áldozat helyébe. Minderre remek megoldás, ha a jelentési rendszer teljesen anonim, hiszen ezáltal elkerülhető, hogy kiderüljön az informátor kiléte. Mindehhez nem szükséges óriási anyagi befektetés, a szerzők szerint elegendő egy levelezőláda kihelyezése is az iskola épületében, természetesen olyan helyen, ahol könnyen hozzáférhető, de diszkréten megközelíthető a diákok számára. Esetleg elektronikus formában is létrehozható anonim jelentési rendszer, amelyre példát is mutatnak a szerzők egy formanyomtatvány-minta útján.

Az említett megoldási lehetőségek mellett a könyv felhívja a figyelmet arra, hogy sokszor az áldozatok nem retorziót kívánnak, hanem a probléma megszűnését. Ebből kifolyólag szerintük megfontolandó a tartalomszolgáltató megkeresése is a tartalom eltávolítása érdekében, ugyanis számos cybermegfélemlítést megvalósító magatartás sérti az adott tartalomszolgáltató felhasználási feltételeit is. Véleményem szerint azonban ez nem jelent megoldást a problémára, hiszen a feltöltött tartalmat az elkövető általában egy elektronikai eszközön tárolja, így egy másik tartalomszolgáltatónál való bejelentkezéssel folytathatja a korábbi cselekményt. Szemléltetésként, ha az elkövető létrehoz egy Facebook-csoportot, amelyben megfélemlíti az áldozatot, majd a Facebook, jelentés alapján, eltávolítja a csoportot, a teljes tartalom áttölthetö egy másik közösségi oldalra.

Az iskolai alkalmazottak mellett a szerzők a szülők számára is segítséget kívánnak nyújtani a megfelelő válaszreakció kiválasztásában. Elsőként kiemelik, hogy az elektronikai eszközöktöl való eltiltás nem a megfelelö megoldás, s a gyermeknek, különösen az áldozatnak, a feltétlen támogatás a legjobb szülöi válasz. Ugyanakkor konkrét javaslatokat is megfogalmaznak, amelyek között szerepel például a bizonyítékgyüjtés és a megfelelő szervekkel való kapcsolatfelvétel. Természetesen nemcsak áldozati oldalon találhatók szülők, hanem elkövetői oldalon is, s a könyv számukra is táblázatban foglalja össze a legfontosabb teendőket. Az előzőekben felsoroltakhoz képest azonban e válaszreakciók nem elég konkrétak és specifikusak (például a cybermegfélemlítés káros hatásairól való beszélgetést, észszerủ következmények alkalmazását vagy a felállított szabályokhoz való ragaszkodást említik). Egyedül a követöszoftver telepítésére való felhívás nyújt kézzelfogható segítséget az elkövető szüleinek.

A tanárok és szülök mellett a tinédzserek maguk is küzdhetnek a jelenség ellen. Ennek módjait már konkrétabban megfogalmazzák a szerzők egy összefoglaló táblázatban. Néhány tanács a fiatalok számára: kerüld a kisebb csúfolódást, blokkold az idegenek leveleit, vagy gyüjtsd össze a téged ért támadásokat, $s$ amint elégnek érzed a bizonyíték mennyiségét, beszélj róla egy olyan felnőttel, akiben megbízol. A szerzők a bystander (szemlélö) pozícióban lévő diákok számára is összeállítottak 
egy rövid listát, amely rendkívül hasznos. A cybermegfélemlítést elkövető diákok számára azonban nem ad tanácsot a könyv. Véleményem szerint ez egy nagy hiányosság, hiszen a korábbi fejezetekben maga a kötet is említ olyan eseteket, ahol az elkövetök maguk állítják, hogy nem mérték fel cselekményük súlyát, $s$ ha tudták volna, hogy tettük milyen hatással van a másik félre, azonnal felhagytak volna a cybermegfélemlítéssel. Éppen ezért számukra is indokolt lett volna táblázatba foglalni néhány hasznos tanácsot.

A fejezet zárásaként a szerzők néhány polgári jogi megoldást, úgynevezett tortot (magyar terminológiával leginkább a szerződésen kívüli károkozás fogalmával írható le) mutatnak be nagyon röviden. Habár mindezek valóban válaszlépések a cyber-megfélemlítésre, véleményem szerint mégis inkább a jogi fejezetben lett volna indokolt elhelyezni őket, ezáltal alkotva teljes jogi körképet a jelenségröl. Mi több, mivel ezen jogi lépések valóban megoldást nyújthatnak adott körülmények között, bővebb kifejtésük mindenképpen kívánatos lett volna. Ettöl függetlenül elmondhatjuk, hogy egy rendkívül informatív, szinte minden lehetséges válaszreakciót felvonultató, konkrét megoldásokkal szolgáló fejezet zárja le a művet, amely valamennyi olvasó számára útmutatást nyújt, s így a könyv hủ marad kézikönyvjellegéhez.

Habár a tartalmi elemzés lezárul e fejezettel, az ezt követő különböző mellékletek tovább erősítik a mű kézikönyvjellegét. Ezek között találunk cybermegfélemlítésről szóló vitához szükséges vitaindító eseteket, technológiahasználatra vonatkozó mintaszerződést, amelyben a gyermek és a szülő elvárásait is felsorolják, valamint egy mintakérdőívet, amely segítségével további kutatások végezhetők. A könyv az iskolák részére jelentéstételi formanyomtatvány-mintákat is rendelkezésre bocsát, továbbá minden fejezethez megfogalmaz olyan kérdéseket, amelyek szakszerü megbeszélésével fejleszthető az iskolai dolgozók cybermegfélemlítéssel kapcsolatos tudása, ismeretanyaga.

\section{4. Összegző gondolatok}

A recenzált mủ az egyik legátfogóbb és legrészletesebb könyv, amely a cybermegfélemlítéssel foglalkozik, még a szakirodalomban bővelkedő USA-ban is. Műfaját kézikönyvként határozzák meg szerzői és olvasói is, s e müfajnak teljes mértékben megfelel.

Logikus felépítésủ, átgondolt, mindenki számára érthető nyelvezettel kalauzolja végig az olvasót a cybermegfélemlítés jelenségének egyes aspektusain, kitérve kialakulásának lehetséges indokaira, társadalmi, müszaki és jogi vonzataira is. Egyik legnagyobb pozitívuma, hogy a felvetett problémákra igyekszik minden érintett félre vonatkozóan válaszokat is adni, valamint mintakérdésekkel és formanyomtatványmintákkal igyekszik segíteni azokat a csoportokat, amelyek napról napra szembenéznek a cyberbullying káros hatásaival. Figyelemre méltó, hogy a könyv egyes fejezetei 2007-re visszanyúló kutatásokból vonnak le következtetéseket. A szerzők ugyanakkor nemcsak saját kutatási eredményeik alapján mutatják be a jelenséget, hanem számos hasonló kutatást is ismertetnek és elemeznek. Néhol kritikával illethető a nem kellő részletezettség vagy a szerkezetben történő elhelyezés, mindezek azonban a mü egészének kivételes értékéből semmit sem vonnak le. 
Magyar kutatóként e könyv olvasását követően hazánkban is égető szükségét érzem egy hasonló munka elkészítésének, hogy közeledjen a társadalmi és jogi kultúra szintje egymáshoz. Magyarországon jelenleg a cybermegfélemlítés elleni küzdelem intenzitása rendkívül alacsony. Ugyanakkor 2015-ben Szegeden hazánk első országos cybermegfélemlítéssel kapcsolatos konferenciája is bizonyította, hogy a szakma már észlelte a jelenséget, illetve annak veszélyeit. ${ }^{5}$ Néhány fontos kezdeményezés már elindult, például a TABBY in Internet program, amely elsőként mérte fel hazánkban a jelenséget, ${ }^{6}$ illetve a Felelős Társadalomért Közhasznú Alapítvány 2013 óta működő Megfélemlítés Elleni Programja. 2016 elején az Oktatáskutató és Fejlesztő Intézet megvásárolta a KiVa elnevezésü finn anti-bullying (megfélemlítésellenes) programot, ${ }^{8}$ sajnos azonban a közigazgatási szervezetrendszerben történő jelenlegi változások miatt a program nem indult el. Történtek tehát szakmai lépések a cybermegfélemlítés ellen, a témáról azonban a recenzált mühöz hasonló átfogó, iránymutatásul szolgáló kézikönyv még nem jelent meg.

Ez a könyv nem csak jogászok vagy társadalomkutatók számára ajánlható. Hasznos ismereteket nyújt tanároknak, diákoknak és azoknak a szülöknek is, akiknek számítógépet, internetet használó - vagy ezek megismerése előtt álló - gyermeke van. Megérthetjük általa, hogy mi mindent foglal magában a cyber-megfélemlítés jelensége, s miként lehet megelőznünk, illetve kezelnünk annak veszélyeit, hatásait.

5 Mikes Lili: Magyar Országos Cyberbullying Konferencia - MOCK 2015. Közjogi Szemle, 2016/1, 65-67.

6 PARTI Katalin-Schmidt Andrea-NéRAY Bálint-VIRÁG György: TABBY in Internet - Az online bántalmazás volumenének iskolai felmérése és mentorképzés Magyarországon (2011-2014). Ügyészek Lapja, 2014/3-4, 47-58. Bővebben a programról: http://tabby-hun.weebly.com/.

7 A Nemzeti Média- és Hírközlési Hatósággal együttműködve a Felelős Társadalomért Közhasznú Alapítvány 2013-2015 között pilotjelleggel működtette a Megfélemlítés Elleni Programot (MEP). A MEP-pilot 2015. március 31-én sikeresen lezárult, azonban müködése folytatódik a pilotiskolákban. Bővebben: http://www. megfelemlites.hu/.

8 Sólyom Nagy Fanni: KiVa - A finn iskolai bántalmazás elleni program, ofi.hu, 2016. január 28. http://ofi.hu/hir/ kiva-finn-iskolai-bantalmazas-elleni-program (2016. 09. 01.). 